\title{
Unexpected Difficulties in Randomizing Patients in a Surgical Trial: A Prospective Study Comparing Extracorporeal Shock Wave Lithotripsy with Open Cholecystectomy
}

\author{
P.W. Plaisier, M.D., ${ }^{1}$ M.Y. Berger, M.D., ${ }^{2}$ R.L. van der Hul, M.D., ${ }^{1}$ H.G.T. Nijs, M.D., ${ }^{3}$ R. den Toom, M.D., ${ }^{1}$ \\ O.T. Terpstra, M.D., ${ }^{4}$ H.A. Bruining, M.D. ${ }^{1}$ \\ ${ }^{1}$ Department of General Surgery, University Hospital of the Erasmus University Rotterdam, 3015 GD Rotterdam, The Netherlands \\ ${ }^{2}$ Institute for Medical Decision Making, Erasmus University Rotterdam, Rotterdam, The Netherlands \\ ${ }^{3}$ Department of Epidemiology, Municipal Health Services Rotterdam, Rotterdam, The Netherlands \\ ${ }^{4}$ Department of Surgery, University Hospital Leiden, Leiden, The Netherlands
}

\begin{abstract}
Shortly after extracorporeal shock wave lithotripsy (ESWL) was introduced as a promising new treatment modality for gallstone disease, a randomized controlled study was performed to assess the cost-effectiveness of ESWL compared to open cholecystectomy, the gold standard. During the performance of this study it was found that during a 3-year intake period only $8.3 \%$ (37 of 448) of the patients could be entered into the trial. Three factors were identified that hampered patient accrual: (1) restricted eligibility for ESWL (and thus for the study), which could not have been predicted on the data provided in the literature; (2) the introduction of laparoscopic cholecystectomy; and (3) strong patient preference, inhibiting randomization. All three mechanisms could not have been predicted during the design phase of the study. It is concluded that it is not always feasible to conduct a randomized study in surgery due to unforeseen circumstances. Entering patients into surgical trials is difficult in quickly evolving fields of surgery, such as the management of gallstone disease. Acquiring informed consent is also difficult when treatment characteristics are divergent. A randomized controlled study on the effects of laparoscopic cholecystectomy will therefore probably never be performed.
\end{abstract}

Gallstone disease is an important clinical problem in Western countries and traditionally considered a surgical problem. It is generally agreed that open cholecystectomy is the standard therapy for symptomatic gallstones $[1,2]$. Still, much effort is put into the development of alternative, preferably noninvasive, treatment modalities for gallstone disease [3]. One of these recently developed, noninvasive, treatment modalities is extracorporeal shock wave lithotripsy (ESWL). The initial results of ESWL to treat gallbladder stones were promising [3-5].

Because of the possible positive clinical and economic consequences of ESWL, we started a study on the effects of this new technique and its cost-effectiveness [6]. We chose a randomized controlled design because randomized studies are considered to provide the most reliable information for proper evaluation of new techniques [7-14]. Moreover, in this way discussions could be avoided, similar to the ones that developed after the general

Correspondence to: P.W. Plaisier, M.D. adoption of ESWL of kidney stones: This treatment modality almost completely displaced open surgery without a randomized study ever being performed [15-17].

During the performance of our study, several problems were encountered in acquiring adequate patient accrual. In this paper we describe the difficulties we met in this area.

\section{Patients and Methods}

To ensure optimal patient accrual for our randomized study, a surgical outpatient clinic solely for gallstone patients was started. Over a 3-year intake period, 596 patients visited this outpatient clinic.

All patients were analyzed according to protocol. A history was obtained and a physical examination performed for all patients. Using the Roma Working Group definition [18], patients were diagnosed as either symptomatic or asymptomatic. Asymptomatic patients were excluded from further analysis and did not receive therapy. With symptomatic patients the various therapeutic options were discussed, and these patients underwent further analysis: laboratory tests and radiologic examination.

Laboratory tests consisted of liver function tests for screening on common bile duct stones. Radiologic examination comprised ultrasonography (US) and oral cholecystography (OCG). OCG was not performed if the patient refused ESWL as a therapeutic option or if a previous US examination already excluded the patient from ESWL (Table 1).

At the end of analysis, all eligible patients were informed about the study and were asked to consent to be randomized. When informed consent was given, therapy was randomly assigned, and self-administered health questionnaires and interviews were undertaken at $0,3,6,12,18$, and 24 months. If patients did not want to participate in the study, they received the therapy of their choice.

The study protocol was approved by the Medical Ethics Com- 
Table 1. Selection criteria for entering the Rotterdam Gallstone Study (ESWL of gallstones versus open cholecystectomy).

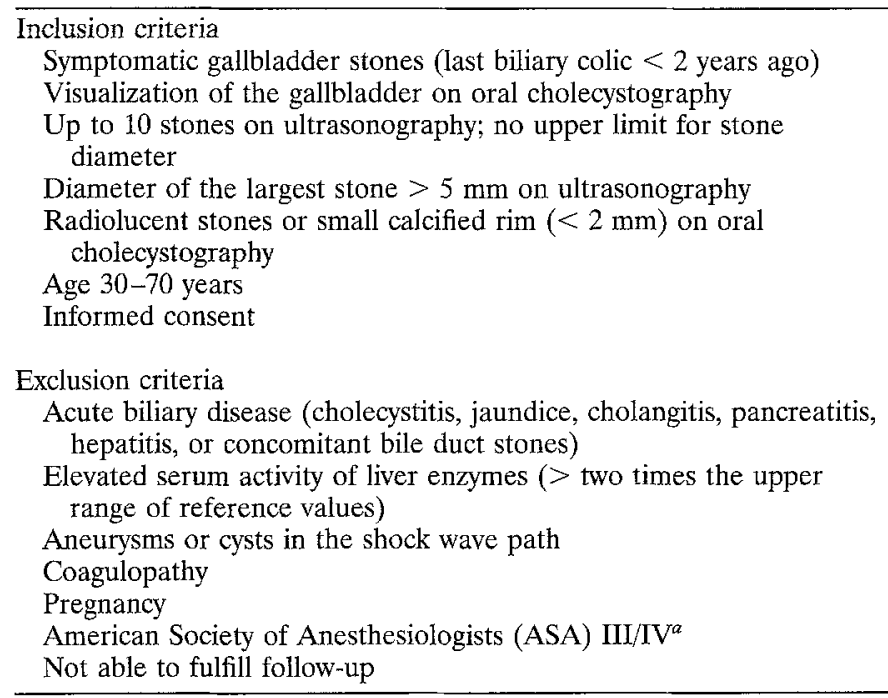

ESWL: extracorporeal shock wave lithotripsy.

${ }^{a}$ ASA III: severe systemic disease limiting activity but not incapacitating; ASA IV: incapacitating systemic disease.

mittee of the University Hospital "Dijkzigt" and the Erasmus University.

\section{Results}

From April 1989 to April 1992, 596 (successively, 238, 179, and 179 per year) patients visited the outpatient clinic. A total of 367 patients $(61.6 \%)$ were referred by their general practitioner, 141 $(23.7 \%)$ by specialists, and $88(14.8 \%)$ visited on their own initiative. A group of 584 patients (98.0\%) underwent US and 345 $(57.9 \%)$ OCG.

There were 12 patients who discontinued analysis, and 96 patients were not symptomatic (Table 2). Of 488 patients, potentially randomizable, $310(63.5 \%)$ were excluded because they did not meet the entry criteria (Table 1). Another 141 patients $(28.9 \%)$ were excluded because they denied random assignment of therapy. Hence 37 patients $(18,12$, and 7 for each year, respectively) consented to enter the study, which is $6.2 \%$ of the total number of analyzed patients and $7.6 \%$ of the patients potentially randomizable. There were 18 patients randomized for cholecystectomy and 19 for ESWL.

\section{Discussion}

There is unanimous agreement that new treatment techniques should be introduced in a manner that allows proper evaluation [7]. Although randomized studies have specific problems, they are considered to provide the most reliable information for such evaluation $[7-14,19]$. The mechanism of allocating patients to different treatment schemes by randomization is accepted almost without question now [10].

New surgical techniques are considered more difficult to evaluate than new drugs $[16,20]$. In fact, most clinical research in surgery relies on comparison with historical or contemporary nonrandom controls [11]. One of the most striking examples of
Table 2. Reasons for not entering the study.

\begin{tabular}{llrrll}
\hline & \multicolumn{2}{l}{ Excluded } & & \\
\cline { 2 - 4 } Parameter & Total no. & \multicolumn{1}{c}{ No. } & $\%$ & Reason for exclusion \\
\hline Referred & 596 & 12 & 2.0 & Discontinuation of analysis \\
& 584 & 96 & 16.1 & Not symptomatic \\
Symptomatic & 488 & 86 & 14.4 & Age \\
& 402 & 224 & 37.6 & Contraindications to ESWL \\
& 178 & 66 & 11.1 & Preference for cholecystectomy \\
& 112 & 75 & 12.6 & Preference for ESWL \\
Eligible & 37 & & $6.2^{a}$ & \\
\hline
\end{tabular}

ESWL: extracorporeal shock wave lithotripsy.

${ }^{a}$ This group comprised $7.6 \%$ of 488 potentially randomizable patients.

this phenomenon is ESWL of renal and ureteric calculi, which completely displaced open surgery [15]. This development consequently led to much discussion, as no randomized study was ever performed $[16,17]$. When ESWL was introduced for the disintegration of gallbladder stones, it was therefore suggested that the proper assessment of the role of ESWL should be dealt with in the context of a randomized trial [3].

During the performance of our study, only a few patients could be randomized. It should be noted here that despite this poor patient entry it was decided to continue the study because (1) interim analysis showed some interesting points; (2) five other hospitals decided to participate in the study; and (3) a large number of nonrandomized patients were entered into the study. However, because this point is not the subject of this manuscript it is not discussed here.

Poor patient entry was due to three mechanisms that could not have been predicted when the study was designed: (1) Contrary to the data in the literature, eligibility for ESWL was found to be limited. (2) Yet another alternative treatment of gallbladder stones was introduced during the performance of our study. (3) Strong patient preference for one of the two treatment arms was encountered that inhibited randomization.

\section{Restricted Eligibility for ESWL}

Partial applicability had already been reported by Sackmann and coworkers [4], but this point was not considered a major obstacle for our study, as we had reasons to assume that our eligibility rate would be higher than that reported by the Munich group, because our entry criteria (Table 1 ) were much wider than those of the Munich group, especially with regard to the maximum number of stones (10 versus 3 ), and another research group had reported a randomization rate of $57.1 \%$ in a trial comparable to ours [21] Moreover, even at Sackmann et al.'s eligibility rate of $28 \%$, accrual of 160 patients-estimated to be necessary to detect any clinically relevant differences in the two treatment options-was considered to be easily achieved within 3 years at our referral rate of approximately 200 patients per year.

\section{Introduction of Another Altemative Treatment}

Shortly after our study was started, a new variant of classic cholecystectomy was introduced: laparoscopic cholecystectomy $[22,23]$. Compared to the "open" technique, laparoscopic chole- 
Table 3. Baseline characteristics between cholecystectomy and extracorporeal shock wave lithotripsy.

\begin{tabular}{|c|c|c|}
\hline Characteristic & Cholecystectomy & ESWL \\
\hline$\overline{\text { Outpatient procedure }}$ & - & + \\
\hline General anesthesia & + & - \\
\hline Curative & + & - \\
\hline $\begin{array}{l}\text { Probability on stone } \\
\text { recurrence }\end{array}$ & - & + \\
\hline $\begin{array}{l}\text { Biliary colic after initial } \\
\text { therapy }\end{array}$ & $0 \%$ & $35 \%$ \\
\hline Morbidity & $10-30 \%$ & $<5 \%$ \\
\hline Mortality & $0.1-0.3 \%$ & $0 \%$ \\
\hline Adjuvant treatment ${ }^{a}$ required & - & + \\
\hline
\end{tabular}

ESWL: extracorporeal shock wave lithotripsy.

${ }^{a}$ Orally administered bile acids.

cystectomy is reported to have several advantages. It is accompanied by less morbidity and mortality and consequently by a reduction in duration of hospitalization, the time to return to full activity, and the need for analgesic drugs. Also for cosmetic reasons, laparoscopic cholecystectomy is more attractive. Laparoscopic cholecystectomy is now considered the gold standard [24] even though this technique has not been studied in the context of a randomized trial.

\section{Strong Patient Preference}

Many mechanisms can lead to strong patient preference. Two mechanisms limited accrual in our case: adherence to new technologies and the divergent character of the two treatment arms. The lay press probably reinforced these two mechanisms.

Adherence to New Technologies. Emotional adherence to a new technology is considered a major obstacle for randomization, and it may become insurmountable if it has become known to the general public [13]. We encountered this phenomenon twice: at the beginning of the study when patients specifically chose ESWL, and at a later stage of the trial when patients specifically opted for laparoscopic cholecystectomy.

Divergent Character of the Two Treatment Arms. Strong patient preference also occurs when the treatment modalities studied are divergent [25, 26]. ESWL and cholecystectomy have indeed different characteristics (Table 3); and because the outcomes of these characteristics were so clear to many patients they specifically opted for a certain treatment modality and simply rejected random assignment.

It has been recognized that comparing treatment regimens with divergent characteristics is difficult [27]: Only $2 \%$ of eligible patients are recruited in breast cancer trials in the United States [28]; and in a trial comparing mastectomy and conservation surgery in Great Britain fewer than half of the eligible patients could be recruited [29]. Recently, some of the large trials comparing percutaneous transluminal coronary angioplasty (P'TCA) and coronary artery bypass graft (CBAG) have also had to stop patient intake without having recruited the desired number of patients [30].

In the field of gallstone management, a trial comparing laparoscopic cholecystectomy and the "mini-cholecystectomy" suffered from a high withdrawel rate after randomization, and this trial was eventually stopped because of difficult patient recruitment [31]. The only alternative to overcome this particular problem clearly would have been to randomize patients without their informed consent, analogous to the European Carotid Surgery Trial [32].

Role of the Lay Press. The role of the lay press in hampering patient accrual has been recognized [29]. In our study the lay press played an important role in promoting patient preference. In some popular magazines the success of ESWL and of laparoscopic cholecystectomy were exaggerated, and the possibility of failure and complications were underestimated or not mentioned at all, which promoted the patient preference to a large extent. As a consequence, the universal adoption of laparoscopic cholecystectomy has been patient-driven $[33,34]$ as a result of media exposure [35].

\section{Conclusions}

Our data confirm that proper information on the feasibility of a trial is not always available before the study is started [35]. Our data also confirm that it is not always feasible to conduct a randomized study because of inadequate patient accrual [9].

Furthermore, we confirmed that acquiring informed consent is much more difficult if treatment characteristics are divergent and that comparing different forms of therapy in a randomized study is hazardous in the quickly evolving field of surgery, such as the management of gallstone disease. It is therefore equally true that a prospective controlled study on the effects of laparoscopic cholecystectomy cannot be performed [7, 36]. In such cases alternatives to randomized studies must be used $[8,13,26,37]$.

\section{Résumé}

Peu après l'introduction de la lithotritie par ondes de choc extracorporelles (LOCE) comme modalité thérapeutique nouvelle dans la lithiase biliaire, nous avons commencé une étude randomisée pour évaluer le coûts de la LOCE comparée à la cholécystectomie traditionnelle, le "gold standard". Pendant cette étude s'étalant sur une période de trois ans, il n'a été possible, cependant, d'inclure que $8.3 \%$ seulement (37/488) des patients éventuellement éligibles. Trois facteurs pouvant empêcher le recrutement ont pu être identifiés. Premièrement, un nombre limité de patients éligibles pour la LOCE (et donc pour l'étude), fait imprévisible selon les données de la littérature, deuxièmement, l'introduction de la cholécystectomie par coelioscopie et son retentissement sur l'aspect thérapeutique de la lithiase, et troisièmement, la préférence du patient, refusant la randomisation dans un bon nombre de cas. On conclue qu'il n'est pas toujours aussi facile de conduire une étude randomisée en chirurgie, en raison des circonstances imprévues. Entrer des patients dans un essai est très difficile dans des domaines qui évoluent vite, tel que le traitement de la lithiase biliaire. Obtenir le consentement éclairé est également difficile lorsque les modalités thérapeutiques sont très divergentes. Il est probable que la réalisation d'une étude randomisée et contrôlée sur les effets de la cholécystectomie coelioscopique ne verra jamais le jour. 


\section{Resumen}

Al poco tiempo de la introducción de la litotricia extracorpórea (LEC) como un promisoria y novel modalidad terapéutica para la enfermedad litiásica biliar, se realizó un estudio randomizado para evaluar la efectividad en cuanto a costo en comparación con la colecistectomía abierta, que es el "patrón oro". Se encontró que en los 3 años del período de ingreso de pacientes al estudio, sólo $8.3 \%(36=7 / 448)$ de los pacientes pudieron ser ingresados, habiéndose identificado tres que interfirieron con el reclutamiento. Primero, la restringida elegibilidad para LEC (y por consiguiente para el estudio), lo cual no era predecible con base en la información de la literatura. Segundo, la introducción de la colecistectomía laparoscópica. Tercero, una fuerte preferencia por parte del paciente, lo cual inhibía la randomización. Ninguno de estos mecanismos podía ser previsto durante la fase de diseño del estudio. La conclusión es que no siempre es factible conducir estudios randomizados en el campo de la cirugía, debido a circunstancias imprevistas. Ingresar pacientes a ensayos clínicos en cirugía es difícil cuando se trata de campos de rápida evolución, como lo es del manejo de la colelitiasis. También es difícil lograr el consentimiento informado cuando las características de las formas de tratamiento son muy divergentes. Es por ello, que posiblemente nunca se hará un estudio randomizado sobre los efectos de la colecistectomía laparoscópica.

\section{Acknowledgments}

The Rotterdam Gallstone Study was supported by both the Dutch Ministry of Education and the Dutch National Health Insurance Council.

\section{References}

1. McSherry, C.K.: Cholecystectomy: the gold standard. Am. J. Surg. 158:174, 1989

2. Soper, N.J., Dunnegan, D.L.: Summary of NIH consensus development conference "gallstones and laparoscopic cholecystectomy." World J. Surg. 17:21, 1993

3. Vergunst, H., Terpstra, O.T., Brakel, K., Laméris, J.S., van Blankenstein, M., Schröder, F.H.: Extracorporeal shock wave lithotripsy of gallstones: possibilities and limitations. Ann. Surg. 210:565, 1989

4. Sackmann, M., Delius, M., Sauerbruch, T., et al.: Shock-wave lithotripsy of gallbladder stones: the first 175 patients. N. Engl. J. Med. 318:393, 1988

5. Burhenne, H.J.: The promise of extracorporeal shock-wave lithotripsy for the treatment of gallstones. Am. J. Roentgenol. 149:233, 1987

6. Nijs, H.G.T., den Toom, R., Berger, M., Lubsen, J., Terpstra, O.T.: Extracorporeal shock wave lithotripsy versus cholecystectomy: the need for randomized clinical trials. J. Lithotripsy Stone Dis. 3:112, 1991

7. Neugebauer, E., Troidl, H., Spangenberger, W., Dietrich, A., Lefering, R., Cholecystectomy Study Group: Conventional versus laparoscopic cholecystectomy and the randomized controlled trial. Br. J. Surg. 78:150, 1991

8. Zelen, M.: A new design for randomized clinical trials. N. Engl. J. Med. 300:1242, 1979

9. Van der Linden, W.: Pitfalls in randomized surgical trials. Surgery $87: 258,1980$

10. Brewin, C.R., Bradley, C.: Patient preferences and randomised clinical trials. B.M.J. 299:313, 1989
11. Pollock, A.V.: The rise and fall of the random controlled trial in surgery. Theor. Surg. 4:163, 1989

12. Russell, P.S.: Commentary on "The rise and fall of the random controlled trial in surgery." Theor. Surg. 4:169, 1989

13. Olschewski, M., Schumacher, M., Davis, K.B.: Analysis of randomized and nonrandomized patients in clinical trials using the comprehensive cohort follow-up study design. Controlled Clin. Trials 13:226, 1992

14. Challah, S., Mays, N.B.: The randomised controlled trial in the evaluation of a new technology: a case study. B.M.J. 292:877, 1986

15. Kahn, R.I.: Early United States experience with the EDAP LT 01 piezoelectric shock wave lithotripter. J. Lithotripsy Stone Dis. 1:224, 1989

16. Dudley, H.A.F.: Stones, lithotripters, trials and arguments. B.M.J. 292:846, 1986

17. Wiser, L.C., Plain, R.H., Dossetor, J.B.: Kidney stones and lithotripters: critical analysis of the introduction of extracorporeal shock wave lithotripsy into Canada. Can. Med. Assoc. J. 143:1299, 1990

18. Paumgartner, G., Carr-Locke, D.L., Roda, E., Thistle, J.L.: Biliary stones: non-surgical therapeutic approach. Gastroenterol. Int. 1:17, 1988

19. MacIntyre, I.M.C.: Tribulations for clinical trials: poor recruitment is hampering research. B.M.J. 302:1099, 1991

20. Spodick, D.H.: Numerators without denominators: there is no FDA for the surgeon. J.A.M.A. 232:35, 1975

21. Milner, P.C., Nicholl, J., Westlake, L., et al.: The design of a randomized controlled trial for the evaluation of lithotripsy as a treatment for gallstones. J. Lithotripsy Stone Dis. 1:122, 1989

22. Southern Surgeons Club: A prospective analysis of 1518 laparoscopic cholecystectomies. N. Engl. J. Med. 324:1073, 1991

23. Cushieri, A., Dubois, F., Mouiel, J., et al.: The European experience with laparoscopic cholecystectomy. Am. J. Surg. 161:385, 1991

24. Schirmer, B.D., Edge, S.B., Dix, J., Hyser, M.J., Hanks, J.B., Jones, R.S.: Laparoscopic cholecystectomy: treatment of choice for symptomatic cholelithiasis. Ann. Surg. 213:665, 1991

25. Oetinger, W., Beger, H.G.: Commentary on "The rise and fall of the random controlled trial in surgery." Theor. Surg. 4:170, 1989

26. Angell, M.: Patient's preferences in clinical trials. N. Engl. J. Med. 310:1385, 1984

27. BARI, CABRI, EAST, GABI, AND RITA: Coronary angioplasty on trial [editorial]. Lancet 335:1315, 1990

28. DeVita, V.T.: Breast cancer therapy: exercising all our options. $\mathbf{N}$. Engl. J. Med. 320:527, 1989

29. Jack, W.J.L., Chetty, U., Rodger, A.: Recruitment to a prospective breast conservation trial: why are so few patients randomised? B.M.J. $301: 83,1990$

30. Breeman, A., Serruys, P.W., van den Brand, M.J.B.M., et aj.: Percutane transluminale coronaire angioplastiek versus coronaire chirurgie bij meervatslijden, een overzicht. Deel 2. Ned. Tijdschr. Cardiol. $8: 238,1992$

31. Barkun, J.S., Barkun, A.N., Sampalis, J.S., et al.: Randomised controlled trial of laparoscopic versus mini cholecystectomy. Lancet 340:1116, 1993

32. European Carotid Surgery Trialists' Collaborative Group: MRC European Carotid Surgery Trial: interim results for symptomatic patients with severe $(70-99 \%)$ or with mild $(0-29 \%)$ carotid stenosis. Lancet 337:1235, 1991

33. Emberton, M., Howerton, R.: Laparoscopic cholecystectomy [letter]. B.M.J. 304:777, 1992

34. Miles, R.H., Carballo, R.E., Prinz, R.A., et al.: Laparoscopy: the preferred method of cholecystectomy in the morbidly obese. Surgery 112:818, 1992

35. Friedman, L.M., Furberg, C.D., DeMets, D.L.: Fundamentals of Clinical Trials. PSG Publishing, Littleton, MA, 1985

36. Carey, L.C.: Cholecystectomy-a new standard. Ann. Surg. 216:617, 1992

37. Hellman, S., Hellman, D.S.: Of mice but not men: problems of the randomized clinical trial. N. Engl. J. Med. 324:1585, 1991 